\title{
Rudolf Goldscheid (1870-1931) and the Economy of Human Beings
}

\section{A new point of view on the decline of fertility in the time of the first demographic transition.}

\section{Gudrun Exner}

\begin{abstract}
The article begins firstly with a short biography of Rudolf Goldscheid both as a fiction writer and as a private scholar mainly in the field of sociology. Secondly, his most important scientific conception, the Economy of Human Beings, and especially its consequences for population policy are discussed. Thirdly, the reception of Goldscheid's ideas by his contemporaries in Austria and Germany is outlined. It is shown that Goldscheid developed modern, stimulating and alternative ideas which were largely ignored by the established scientific community considering their importance. One reason for this might be that Goldscheid never worked out his conceptions in detail.
\end{abstract}

\section{Preliminary remarks}

Who was Rudolf Goldscheid? Because of his individualistic way of life-he was a fiction writer, a universal and private scholar, a pacifist and theoretical social reformer, a member of the middle class and a socialist, an assimilated Jew and a monist-he can not clearly be assigned to any ideological movement or scientific school. At best he might be counted ideologically to the radical middle class of Viennese modernism and late enlightenment, in scientific regard to the early stages of modern sociology. When he occupied himself with the reform of the capitalist social and economic system at his time he also came into contact with demographic issues.

By the example of Goldscheid's concept of the "Economy of Human Beings", this article shall show what stimulating, alternative ideas were developed outside the mainstream of the demographic discourse and largely ignored by the established scientific community—considering the importance which Goldscheid himself attached 
to his life work and the many original thoughts it contained. ${ }^{1}$ Not even the weaknesses of Goldscheid's theory were discussed, and nobody ever tried to disprove him with scientific arguments.

The time shortly after the first demographic transition when Goldscheid developed his theories was dominated by the fear of declining birth rate-in Germany Friedrich Burgdörfer (1890-1967) warned against this danger, in Austria it was Wilhelm Winkler (1884-1984) -, a fear that contributed to an uncritical acceptance of the national-socialist population policy. At that time, the discussion of the alternative population policy outlined by Goldscheid which suggested a careful treatment of the human capital by a social policy instead of simply increasing the birth rate might not have been amiss.

From this point of view, Goldscheid's theories are interesting for the historian and the historically interested demographer, because they might provide some hints to the reasons why Goldscheid managed to escape this fatal way of thinking and suggested a much more human way of solving the problem of a lack of offspring than most established "demographers" ${ }^{2}$ of his era.

\section{Short biography}

Rudolf Goldscheid (picture 1,2) was born in the City of Vienna, Salzgries 23, on 12 August, 1870, as the fifth child of a wealthy Jewish family. Goldscheid had four brothers: Sigmund, Julius, Alfred, Theodor and a sister, Dorothea. His father, Moses Hirsch Goldscheid, had been a merchant and at the time of Rudolf's birth lived as a private gentleman. His mother, Babette or Betty, was the daughter of the merchant Leib Reitzes (Weiss 2003; Neue Deutsche Biographie 1971, 607), her brother, Goldscheid's uncle, was-according to Goldscheid's friend Rosa Mayreder

1 What seems to me especially remarkable is that Goldscheid based his demographic views on a different notion of the state. I would like to put forward the hypothesis—which still needs investigation - that quite a few population scientists (implicitly) had the idea of a state whose aims are a maximum of military force (national security) and economic strength, and population policy was therefore aimed at producing sufficient numbers of productive subjects. Goldscheid instead developed the concept of a state which aimed at the general satisfaction of socially useful needs like education, public health and old-age pension and guaranteed modest welfare for everyone.

2 In using this term I want to indicate a problem of definition: "demography" in the inter-war period was not as clearly defined as nowadays. This branch of science was still developing and was situated between the fields of population statistics and population policy. The German expression at the time was "Bevölkerungslehre" (i. e., "population theory" or "population science"). Professional demographers in today's sense did not exist, the "demographic" discourse was interdisciplinary, disordered and heterogenous, and population statisticians, social politicians, doctors and economists took part in it. So if the terms "demographer" and "demography" are used in this article, they are meant in this sense. 
(1858-1938) - a rich financier who had great influence on the Goldscheid family. For example, when Goldscheid turned socialist or wanted to marry the Christian girl Marie Rudolph ${ }^{3}$, this led to severe quarrels with his uncle (Arco, Hertz and Mayreder 1930, 195).

Goldscheid went to secondary school in Vienna. He started his scientific career at Friedrich-Wilhelm-University in Berlin, where he enrolled in 1891 in order to study philosophy and sociology. Although he was successful in his studies, he left university in 1894 without a degree and merely received a positive leaving certificate. We do not know why Goldscheid dropped out of university. Apparently it was not because of poor performance in his studies, but his ambition was to become a writer. Indeed, between 1888 and 1899 he published a book almost every other year under the pseudonym "Rudolf Golm". In his books he dealt with the issues of love and marriage. His first literary production, the tragedy "Lord Byron" (1888) shows signs of talent but surely is epigonous. The play "Die Logik der Gesellschaft" (1890) and "Venus am Kreuz" (announced in: Golm 1897, no indication if ever published) ${ }^{4}$ are no longer available. "Das Einmaleins des Lebens" (1894) describes, with obvious autobiographical elements, the dilemma of a young man of wealthy background who falls in love with a girl from the lower social classes but neither does he want to marry her nor have his pleasure and abandon her afterwards. The novel "Der alte Adam und die neue Eva" (1895) describes in detail the misery of a marriage of convenience from the woman's point of view. The novelette "Ein falsches Liebeslied" (1897) tells the merry story of a charming playboy who manages to escape from boredom into love and marriage and also contains several autobiographical elements. Goldscheid's last literary production, "Bäume, die in den Himmel wachsen" (1899), could not be found until now either. His works were reviewed, e. g., by the Berliner Tageblatt, the Neue Freie Presse and others (Golm 1895, title page, Golm 1897, title page).

Summing up his literary production, we can say that Goldscheid had some talent as a writer but never reached a top level. For the historian his early books are interesting because some of them seem to contain autobiographic elements and deal with the problems of his time. Goldscheid's creative background seems to have had both positive and negative consequences for his occupation with demographic topics. On the one hand, he took into consideration the fate and the suffering of individual persons and did not see mere numbers in them-like many population statisticians of his time. For him —other than for the established demographers - the security and wel-

3 When I wrote that he married Marie von Malthzahn (Exner, Kytir and Pinwinkler 2002, 92) this is a mistake which can be traced back to the research literature; the maiden name of the mother of Marie Rudolph/Goldscheid was “von Maltzahn” (Neue Deutsche Biographie 1971, 607).

4 These books and "Bäume, die in den Himmel wachsen" (1899) were not found despite extensive research in all Western European internet library catalogues and in the ZVAB, the internet catalogue of second-hand bookshops. "Das Einmaleins des Lebens" was ordered from a second-hand bookshop in Dresden. Apart from that, it could only be found in the British library. The other books are still available in the great Vienna libraries. 
fare of the individual was more important than national welfare and security. On the other hand, his occupation with demographic topics always remained at the dilettante level. Of course, in his times sociology was not yet a fully developed science with precise methods. Anyway, his ideas and theories often lack an exact elaboration in detail, e. g., by the use of statistical methods, which were quite well developed already at this time.

His novels reveal some traits of his character (such as thoughtfulness, sociability, sympathy for other people, interest in psychological problems, trying to understand and explain people's motivations, a tendency to analyse his own feelings, etc.). But how did his contemporaries, his friends and colleagues, describe him? The Viennese feminist writer Rosa Mayreder ${ }^{5}$ often mentioned Goldscheid in her diaries in the years from 1910 to 1934. She appreciated him as the reviewer and supporter of her literary production but she had also a keen eye for his weaknesses. According to Mayreder, Goldscheid suffered from a lack of energy (in spite of all his activity on the fields of science), and his sensitivity made him unfit for the hardships of life in some regards. He liked endless discussions and often reacted emotionally in situations where Mayreder would have liked to see more restraint. On the other hand, he had a lot of understanding for the incurable mental illness of Mayreder's husband (Anderson 1988).

1898 he married Marie Rudolph (picture 2) in Leipsic. At that time he returned to Vienna and lived there until his death as a very productive private scholar and active member of several scientific societies. In 1908 he was among the founding members of the "Österreichischer Monistenbund" [Austrian Monist Association]. Though he was a Monist-i. e., he rejected traditional religions and believed in one basic principle such as energy - he did not leave the Jewish Community in Vienna until 1921 (Weiss 2003, 1). In 1909 he was also one of the founding members of the "Deutsche Gesellschaft für Soziologie" [German Society for Sociology]. He was a member of the "Soziologische Gesellschaft" [Sociological Society] in Vienna and again among the founders (as vice-president) of the "Österreichische Gesellschaft für Menschenrechte" [Austrian Society for Human Rights]. He also became editor of the "Friedenswarte" [Peace Observatory] (Fleischhacker 2000, 3-5; Fleischhacker 1997, 7 f.). In 1917, Viennese scientists and politicians who were interested in the future development of the Austrian population founded the "Österreichische Gesellschaft für Bevölkerungspolitik" [Austrian Society for Population Policy], with Goldscheid among the founding members as well. Here he could have met the leading population statisticians of the interwar period, Wilhelm Hecke (1869-1945) and Wilhelm Winkler. In 1918 he held a lecture there on "Menschenökonomie und Finanzpolitik" [Economy of Human Beings and Financial Policy]. We only know the title but not the text of this lecture, because it was never published in the review of the society. This review-the only existing source about the Austrian Society for Population Policy_tells us that Goldscheid did not take part in its subsequent con-

5 For the hint on Mayreder's diaries thanks are due to Hans Peter Hye. 
ferences (Mitteilungen 1918-1937). Goldscheid became acquainted with some important scientists in these societies. Thus he made friends with the physicist Wilhelm Ostwald (1853-1932) (Goldscheid 1913) and the sociologist Max Adler (1873-1937) and edited a festschrift for each of them. Goldscheid also worked as a journalist and since 1914 published about 15 articles in the most important Austrian social-democratic newspaper, the "Arbeiter-Zeitung". Most of his articles dealt with the consequences of the First World War (Municipal and provincial library of Vienna, Tagblattarchiv, Mappe "Rudolf Goldscheid"). He was a committed pacifist and social democrat. He was member of the Socialist Party (Rudolf Goldscheid 1930, 3). As a scientist he was mostly interested in sociology. Most of his studies were published: he composed about 20 scientific studies-in most cases books that dealt with sociological, social and economic issues (Fleischhacker 2000, $12 \mathrm{f}$.).

In the field of science, Goldscheid's main achievement was the development of the Economy of Human Beings. He described this concept and its theoretical basis in two studies which appeared already before World War I: the study "Entwicklungswerttheorie, Entwicklungsökonomie, Menschenökonomie" [Axiology of Development, Economy of Development, Economy of Human Beings] in 1908 and the essay "Höherentwicklung und Menschenökonomie. Grundlegung der Sozialbiologie" [Evolution and the Economy of Human Beings. The Foundation of Social Biology] in 1911. The main idea of the Economy of Human Beings said that the labour force must be protected from exploitation and misery, not only for humanitarian reasons but on economic grounds as well. Goldscheid fully described the causal connections between the economic system and the "organic capital". In the interwar period Goldscheid's Economy of Human Beings was well known to Austrian social democrats (Lehner 1989, 54) and even among Austrian statisticians-although Goldscheid was rarely mentioned as its author.

Goldscheid died on 6 October, 1931, quite unexpectedly and much too early for his friends. He seems to have come to a very peaceful end: one of the obituaries describes that on a busy day at home he suddenly felt sick, lost consciousness and was dead one and a half hours later without having woken up again. A few days later, his urn was buried in the crematorium on the Vienna central cemetery. Leading social democrats of Vienna like mayor Karl Seitz (1869-1950) and municipal councillors Julius Tandler (1869-1936) and Hugo Breitner (1873-1946) took part in the burial ceremony, as well as representatives of the organisations for which Goldscheid had worked (Wehberg 1931, 343). About two weeks later, the Vienna municipal council decided that in appreciation of Goldscheid's scientific achievements his urn should get a special place at the inner part of the left-hand arcades of the crematorium (Amtsblatt 1931, 988). Furthermore, the municipal council decided in its meeting of 4 May, 1932, that a street in the $17^{\text {th }}$ city district should be named after Goldscheid (Amtsblatt 1932, 429). All this indicates that Goldscheid must have been a very important person in "Red Vienna". In 1938, when his wife died, his urn was removed from its place of honour in the arcades (it is not quite clear whether the reason was Goldscheid's being Jewish) and put outside into department VI of the crematorium 
next to his wife's urn where the already slightly damaged gravestone can be found even today (Picture 3).

A look at the material goods Goldscheid left behind shows that he had died just in time, as it were. Besides some clothes and furniture he only had about 50,000 Austrian shillings in the bank. He could have lived from that only for a few years. He left no children (records of 1931). When his wife died in 1938, the debts were as high as the remaining money (records of 1938).

\section{The main features of the Economy of Human Beings}

The economic system of the Economy of Human Beings and the history of its development by Rudolf Goldscheid shall be fully described in this section. An understanding of the Economy of Human Beings is the precondition for the full understanding of Goldscheid's views on population policy and his solution to the problem of the declining birth rate. Goldscheid developed his ideas about population policy on the background of this concept. The Economy of Human Beings is the result of long studies in many fields of science: physics, national economy, philosophy and sociology (Fleischhacker 2000, 5-7). A great influence on the development of the Economy of Human Beings was also contributed by the monist, chemist and Nobel Prize winner Wilhelm Ostwald and his "energetic imperative": Do not waste energy, use it! (Weikart 2002, 143; Fleischhacker 2002, 212 f.).

Before Goldscheid developed the Economy of Human Beings, he elaborated something like a prototype, the concept of the Economy of Development. This concept already contains many elements of the Economy of Human Beings, but never became as well-known. Therefore the features of the Economy of Development shall be outlined before describing the essential aspects of the Economy of Human Beings. ${ }^{6}$

Goldscheid's Economy of Development was directed at capitalism in the last consequence, pointing out that capitalism is only interested in profit and not in the real needs of society. Goldscheid's Economy of Development, however, was based on the idea that an economic system must provide useful goods (that meant for Goldscheid: necessary for human development and evolution) which should be produced by the least possible expenditure of human labour and for the greatest possible number of people. Of course, before starting with this kind of economic system, it must be de-

6 When Goldscheid formulated his Economy of Development, he also read Darwin and Marx. In general, he agreed with them, but criticised shortcomings in Marx's theory and misunderstandings in the adoption of Darwin's ideas. His objection to Marx was that he considered only how - i. e., under which working conditions - goods were produced. Goldscheid stressed that it is equally important to see what is produced-i. e. luxury goods which great expenditure of work for a few, or useful goods for everyone (Goldscheid 1908, 45). He approved of Darwin's theory in general, but rejected Darwin's agreement with the population law of Malthus as well as social Darwinism (Fleck 1990, 52) 
termined which goods are necessary and useful and can encourage the development and evolution (the progress) of human society. This should be done with the help of a sociological axiology (Goldscheid 1908, 11-13).

The Economy of Human Beings and the Economy of Development had many similar features, but different priorities. Economy of Development emphasised the importance of the production of useful goods, the importance of "what" is produced. Economy of Human Beings concentrated on the role of man itself in the production process - man was regarded both as object and subject of economy, as labour force and "organic capital" on the one hand, but on the other hand also as the final target and the one who profits. Men and the human society were investigated from a new point of view - the economic perspective (Fleischhacker fully explained this issue in: Fleischhacker 2000, 7-9). Even human beings can be regarded as elements of economy and are subject to its laws. The view on men from the economic perspective was connected with the use of a terminology which might appear somewhat derogatory. Goldscheid spoke of human beings as "organic capital", of reproduction as the "production of men", even of a "profitable production of men", meaning the economically useful reproduction (this will be fully explained below) (Goldscheid 1908, 54). But Goldscheid did not intend to discriminate against human beings. On the contrary, he wanted to put the demand for the protection and human treatment of workers on a solid basis. He thought he could persuade employers more easily with economic arguments than with humanitarian ones (Goldscheid 1908, 118). If people are elements of economy and can be regarded as economic commodities like, e. g., machines, the employer might realise that people_-like machines-must be treated carefully, in order to achieve the greatest profit (together with the greatest possible duration of life). With this argument, Goldscheid hoped to underline the necessity of a welfare, health and school policy - the necessity of a welfare state not only because of humanitarian reasons but also as an economic prerequisite. He hoped that the leading members of society would recognise that the exploitation of the workers entailed a lot of additional costs and could therefore be regarded as economically harmful. Goldscheid stressed that an economic system should have to pay itself for the consequences of exploitation-diseases, invalidity, neglected children and adolescents - and must not produce at the public expense. Thus, capitalism actually worked uneconomically if one took into account the consequences of capitalist production. Goldscheid wrote:

"If we put together the direct and in particular the indirect costs of innumerable occupational diseases, premature exhaustion of the labour force, unsanitary women's work, cheap child labour, insufficient school education, high infant mortality, miscarriages and stillbirths, widespread diseases like tuberculosis and syphilis, alcoholism and prostitution, and if we take into account what the wasteful exploitation, which violently tends to push the envelope of productivity, results in for society, we will realise at once: we are running our household most uneconomically, indulging in a fiction of productivity, and we are paying dearly for this mere illusion." (Goldscheid 1911, 528) 
But for Goldscheid, man was not only labour force and object of economy, but also its profiteer and subject. Thus the economy should focus on the welfare of the whole society and not on the profit of a few at other people's expense. This was the underlying idea of the Economy of Human Beings, which Goldscheid thought to be the better economic system. He wrote:

"Therefore it appears that the basic axiology of the Economy of Development is the theory of the economical value of man for society, and therefore the Economy of Development leads to the Economy of Human Beings, that means to the postulate that we must bring to an end the outrageous waste of human lives, human health and human ability of development which is common in our present economy. The axiology of development demands that we practise not only economy for the people, but economy with the people, that we strive for an efficient use of the organic capital of society!" (Goldscheid 1908, 46)

Like the Economy of Development, the Economy of Human Beings was directed at the capitalist economic system. At Goldscheid's time, capitalism was not kept in check by the welfare state, and there were many reasons why to oppose capitalism. But Goldscheid's concept of the Economy of Human Beings lacked concrete and detailed suggestions how it could be put into practise. A practical realisation of the Economy of Human Beings does not seem possible without the economy being controlled by a strong state. The recent past has shown the disadvantages that planned economies of this type are faced with. But we must concede that at Goldscheid's time there was no such concrete experience with planned economy. Thus Goldscheid could still dream of the "socialist state of the future", "where the state provides for free, to every member of society, the bare necessities of life without implying a reduction of the political rights or a restriction of personal freedom". (Goldscheid 1914, 24) - The all-embracing and nearly totalitarian claim that the economy were to decide not only about the market and its laws but about society and its progress ("evolution") as a whole seems questionable as well. Goldscheid's Economy of Human Beings was also intended as a kind of "makeshift solution" to the problem of the declining fertility. In some passages his book all but degenerates into suggestions about men-breeding (especially: Goldscheid 1911, 508 f.). Furthermore, we must assume that Goldscheid's ideal and abstractly described economic and political system could only work with equally ideal people. But what is lacking in Goldscheid's studies are the psychological preconditions of an Economy of Human Beings, although he thoroughly worked out its sociological and economic elements.

\section{Goldscheid's views on population policy}

In dealing with the Economy of Development and Human Beings, Goldscheid also came across the following issues: the decline of the birth rate, reproduction and the influence of the state on reproductive behaviour. Contrary to Austrian contemporary professional demographers such as Wilhelm Winkler or Wilhelm Hecke, 
Goldscheid did not occupy himself too much with demographic issues-compared to his interest in sociology and economy. In his essays, statistical tables and figures are missing. Besides, in most cases detailed quotations and references are missing, too-but this seems to be typical for many scientific publications at the time. Goldscheid did not compose essays, not even articles, that only dealt with a purely demographic issue. Therefore Goldscheid's views on population policy must be gathered from small and disconnected passages out of his books. When Goldscheid developed his Economy of Human Beings, he also developed a possible solution for the decline of the birth rate. How relevant was his conception of population policy, how much did his proposals differ from those of his contemporaries? These issues shall be investigated in the following sections, analysing Goldscheid's views about the declining birth rate, reproduction and population policy.

\subsection{Goldscheid's views on the decline of the birth rate}

Already before World War I Goldscheid occupied himself with the declining birth rate. He regarded the dropping numbers of births as a "sign of social adaptation" (Goldscheid 1914, 6) and predicted a change of society caused by this demographic transition. On the other hand, like all contemporaries Goldscheid regarded the declining birth rate as a negative sign, even as symptomatic for a possible degeneration (Goldscheid 1908, 205) and warned of the danger of underpopulation, for example in the following passage: "The most serious danger that threatens us is underpopulation against which we would be-at least according to our present knowledge-completely powerless, whereas we possess the most efficient means against the danger of overpopulation." (Goldscheid 1908, 141 f.) But Goldscheid had discovered an remedy: the possibility to counteract the decline of the birth rate by a more careful treatment of the "organic capital", especially by eliminating exploitation and misery. (A similar proposal was made by the Austrian demographer Wilhelm Hecke-he suggested diminishing infant and child mortality-Hecke 1915, 587.) Economy of Human Beings was Goldscheid's solution for the declining birth rate ${ }^{7}$.

7 Goldscheid repeatedly explained, using many variations, what he meant by Economy of $\mathrm{Hu}-$ man Beings. He wrote: "It is quite clear that the process of reproduction goes on much more economically if the same results are achieved by a smaller turnover. Many births, many deaths - this is still a rather extensive economy of human beings. But if the well of reproduction bubbles less abundantly, we have to balance the quantitative minus by a qualitative plus, using the human material more efficiently and not shortening its period of productivity by wasteful exploitation, so that we can achieve an ever increasing profit from the same amount." (Goldscheid 1914, 9) Or in other words: "If fewer children are born, man ceases to be a commodity in abundance. His economic value increases and in the same degree as that happens we must manage this commodity, which becomes more and more scarce, more economically." (Goldscheid 1914, 10) 
Contrary to many contemporaries Goldscheid recognised that war can be an important reason for a decline in fertility or a dropping birth rate:

"We are surely the last to deny that the declining birth rate in certain countries and at different times can be a symptom of degeneration. It will have to be regarded as a symptom of degeneration if it actually means turning away from the bold courage to face life or if it is caused by a pathetic desire for comfort. A most serious symptom of degeneration, however, because it is much more difficult to compensate, is such a decline if it takes place after a period of limitless waste of human beings, such as after the Napoleonic Wars in France when hundred of thousands of people were lead like lambs to the slaughter. Under circumstances like this an exhaustion of the fertile basis of human reproduction can arise. In such cases, the organic capital was wastefully exploited because of the thoughtless delusion that man is an abundant commodity." (Goldscheid 1914, 205 f.)

Though this opinion - that war is a cause of population problems - to us is more than self-evident, it was not for the leading population statisticians at the time. Wilhelm Hecke, later the head of the department of population statistics at the Austrian Federal Statistical Office in Vienna twisted the causal connections: in 1915, he held the view that the basic cause for World War I was the declining birth rate in the Western European countries, especially in France and England, who felt threatened by the high German population numbers (Exner, Kytir and Pinwinkler 2004, $63 \mathrm{f}$.).

But Goldscheid's point of view on the problem of the declining birth rate was not quite clear. On the one hand, the Economy of Human Beings was a possible solution, a theory which also considered the recent modernisation of society. Contrary to some professional Austrian population statisticians like the above-named Wilhelm Hecke, Goldscheid caught the trend of the time, i. e., he recognised that demographic transition and modernisation were related to each other. On the other hand, he rejected the idea that people should have not more than two children unless socio-political measures towards an evolution of society were taken, and warned-like almost all of his contemporaries of the "inundation of the country by immigrants of less developed cultures and foreign racial elements" (Goldscheid 1911,420) as a consequence of the declining birth rate.

\subsection{Goldscheid's views on reproduction}

Goldscheid developed his views on population policy at a time when Malthus's paradigm of overpopulation was still prevalent. Goldscheid stated that Malthus's opinion of a continuous increase of mankind was wrong. Goldscheid also refused Darwin's opinion that a great quantity of men was necessary for the selection and the evolution of a fit species. Goldscheid made clear that Malthus as well as Darwin were used to justify the unscrupulous waste of human lives by wars or by the process of production (Goldscheid 1911, $368 \mathrm{f}$., $392 \mathrm{f}$.). He stressed that man was not an abundant commodity and that, contrary to Darwin's opinion, a lower birth rate could also 
result in a higher quality of the next generation. Thus, Goldscheid wrote in the introduction of his study "Axiology of Development, Economy of Development, Economy of Human Beings" in 1908:

"This book is a protest against the outrageous waste of men which is practised even in our time. It is an indictment against all those who hold and propagate the illusion that man is an abundant commodity which nobody has to use sparingly. It is with the utmost resoluteness that I challenge the view that there is a continuous overproduction of men, as has been unremittingly asserted ever since Malthus. Just like a continuous overproduction of men cannot be regarded as the cause of all social evil, it is even less true that the continuous overproduction of living beings were an indispensable precondition of social evolution." (Goldscheid 1908, IX)

Goldscheid also examined the human reproduction from the economic perspective and from the perspective of the Economy of Human Beings. He suggested that from the point of view of the economic system as a whole, it makes more sense to bring up a lower number of children with a long duration of life than to produce a great number of children who die prematurely because of child labour and misery. In his opinion, a careful treatment of the labour force was necessary if the gained profit was to make up for the costs that society invested in upbringing, education and training. Goldscheid wrote:

"The generation of human labour force is not only a technical, but first of all an organic problem. If the quality of the labour force decreases due to an increase of the birth rate, or if this quality threatens to deteriorate over the course of time, the production of working material will soon prove to be uneconomic. Thirdly: the procreation of the worker material takes place in the manner that every newborn worker, instead of being productive immediately, requires essential expenditure of work for a lot of years; thus we can only speak of profitable breeding of men if the workers, in their period of productivity, produce more than they have need of during their entire lives, including the unproductive years, to satisfy the necessities of their development." (Goldscheid 1908, 54)

I would like to stress once more that by using expressions like "profitable breeding of men" and the economic perspective on reproduction, Goldscheid did not intend to discriminate against human beings. He only wanted to put his demand of protecting workers from exploitation on a more solid basis than he saw in a purely ethical line of argument. Goldscheid thought that the employers regarded any ethical and humanitarian arguments for socialist demands as sentimental humanitarianism but that they would be interested in the economic argument that exploitation causes great disadvantages for the whole society. In the same way, he urged the protection of women against night-work and stood up against child labour:

"If for example children are prematurely put in unhealthy factories to do monotonous work instead of providing them with the necessary education and training to qualify their abilities and to make their organisms as fit as possible, this may seem profitable for the owner of private property, considering the given structure of purchasing power as well as the international economic and military competition. From 
the point of view of the Economy of Human Beings, however, such practises are quite unjustified." (Goldscheid 1908, 126)

But Goldscheid went one step further and spoke about women as the "producers of men", even about the "economic branch of the production of men" and women as the "main employees in this branch of economy". This was not meant in a depreciatory sense either, but intended to substantiate socio-political measures for the protection of women even economically:

"It should be understood that all rights which woman demands must be conceded to her, in the interest of the improvement of the branch of production into which nature forces her, and that the fitness of the race can only build up on the sufficient legal protection of women's organic and reproductive fitness." (Goldscheid 1914, 12)

\subsection{Demands on population policy}

Goldscheid did not have an all-embracing, detailed and concrete concept of how a social and welfare state should work or what a government's population policy should be like. But he stood up for a social welfare state and a public family policy aimed at increasing the birth rate (Goldscheid 1911, 420 f.). He also advocated governmental measures to protect the disadvantaged groups of society such as workers, women and illegitimate children. Here as well he based his demands on the Economy of Human Beings, that means he called for a social policy not for humanitarian but for economic reasons because he thought the latter to be far more convincing. Thus, he recommended establishing an insurance system and a an insurance law, because society then would be interested in the welfare of the insured members and would treat them more carefully in order to save costs. This insurance system should be financed by the economy itself, following Goldscheid's principle that it must bear the consequences of production.

"The insured person's individual fate affects society financially as well, which must lead to the ever more clear knowledge that social policy and social hygienics directly belong to the operational costs of an economy and therefore must not be financed from the funds of the welfare state but from the business capital." (Goldscheid 1914, 12)

In his essay "Question of Women's rights and the Economy of Human Beings" (1914) he dealt with the changed situation of women at his time. Here we find reflections about the female "work of reproduction", about emancipation, women's labour, university education for women, the importance of intellectual women for society, active and passive voting rights for women, and equal rights in marriage. Goldscheid supported all demands of the suffragettes. He recommended emancipation though he knew it would lead to a lower birth rate. Woman, the "producer of man" who has to bear the main burden of reproduction, was to profit most from his Economy of Human Beings. Goldscheid demanded the woman's franchise. In his view, politics would only assume the protection of women and families (for example: provide measures for the maternity protection) if women were given the right to vote (Goldscheid 1914, 16, 30). 
Goldscheid also argued for a better treatment of illegitimate children, because they had to be regarded as especially valuable in a period when there was a lack of children. He acknowledged that society had already taken measures at his time:

"In former times when children were an abundant commodity, the legitimate ones were quite sufficient and the waste of illegitimate offspring could easily be tolerated. Today this has become different. The flow of reproduction begins to become less plentiful, and thus we are forced not only to pay more attention on legitimate births, but also illegitimate children must be cared for with all our attention if we do not want to see a negative balance of the economy of population. [...] Hence all the efforts to reduce infant mortality, for the welfare of youth, maternity protection, maternity insurance, childbed care and many other measures, as well as the trend in the children and maternity protection not to make any differences between legitimate and illegitimate births." (Goldscheid 1914, 11 f.)

\section{The reception of the Economy of Human Beings by Goldscheid's contemporaries}

\subsection{In Austria}

The present research literature does not give any hints about the contemporary reception of Goldscheid's Economy of Human Beings until 1938 with but a few exceptions (Byer 2002; Fleischhacker 2002, 225 f.; Exner, Kytir and Pinwinkler 2004). Goldscheid's concept was scarcely taken note of by the established Austrian demography before 1938 and then often misunderstood, most frequently in the eugenic sense. In Austria it was in particular the social-democratic municipal councillor of Vienna and social reformer Julius Tandler who was interested in the Economy of Human Beings although he did not mention Goldscheid as its author. He used the term every now and then in his publications but did not explain it exactly or discuss it $^{8}$. Tandler understood the Economy of Human Beings correctly as a plea for the careful treatment and protection of human beings but he was also more interested in the eugenic connotations of this concept, i. e., he interpreted it mainly as a system of procreation (Tandler 1917, 1), whereas Goldscheid was first of all interested in reforming the social and economic system. From my researcher's experience with demography and the demographic discourse in Austria in the inter-war period (Exner, Kytir and Pinwinkler 2004), it seems quite likely that Goldscheid's concept was best known in Vienna's socialist circles. Thus Karl Kautsky jun., a colleague of Tandler, briefly mentioned the Economy of Human Beings in one of his publications as well. He considered it a kind of population policy based on a social or socialist welfare state (Kautsky 1924, 31). The established population statisticians of the time, such as

8 The reference to the following article and its connection with the Economy of Human Beings was taken from Byer 2002, 193; but see also Tandler 1916, 451. 
Wilhelm Hecke and Wilhelm Winkler, were not interested in the demographic concept of the outsider Rudolf Goldscheid, although they must have known him as an active member of the Austrian Society of Population Policy (Exner, Kytir and Pinwinkler 2004, Ch. B. 3., B. 4., Ch. D.).

\subsection{In Germany}

As Goldscheid took part in international conferences and was a member of international societies, the Economy of Human Beings was also known in Germany. There his ideas were, like in Austria, not so much absorbed by professional population statisticians such as Friedrich Burgdörfer ${ }^{9}$, but rather by social hygienists, by the sexual reform movement, in medicine and eugenics. The following section can only give hints on some "trends" in the reception of Goldscheid's "Economy of Human Beings" and, of course, does not intend to go into the details of Goldscheid's influence on the entire socio-political discourse in Germany from WWI to the end of the Weimar republic. (This would indeed be material for an article of its own.) The social hygienist Alfred Grotjahn (1869-1931) mentioned it—without naming Goldscheid as its originator-in his book "Geburtenrückgang und Geburtenregelung" [The decline of the birth rate and birth control] (1914), but misunderstood it as a synonym for "population policy" and was like Tandler mainly interested in its eugenic implications. Grotjahn understood the Economy of Human Beings as the "economising of men" by reducing infant and child mortality but also by the prevention of the reproduction of "inferior people" (Grotjahn 1914a, 363 f., identical also: Grotjahn 1914b, 163). Grotjahn used Goldscheid's theories to support his own interests ${ }^{10}$.

The radical feminist and eugenicist Henriette Fürth briefly quoted Goldscheid in her work "Das Bevölkerungsproblem in Deutschland" [The Population Problem in Germany] (1925). Here she used the term "Economy of Human Beings" in the eugenic sense as the production of high-quality human capital (Fürth 1925, 105 f.). She described Goldscheid's theory more fully in her book "Die Regelung der Nachkommenschaft als eugenisches Problem" [Birth Control as a Eugenic Problem] (1929). Here she stressed the humanitarian aspect of Goldscheid's conception, because for him the first goal to which all other goals must be subordinated, was modest

9 Burgdörfer used the term "Economy of Human Beings" as a synonym for "population policy" (Burgdörfer 1932, 22).

10 This quotation by Grotjahn was found more or less by accident. Further hints on the reception of the Economy of Human Beings in Germany might be found by specialists on the literature by the Monist movement around Wilhelm Ostwald who was a friend of Goldscheid's (Goldscheid 1913), or on the sexual reform movement around Helene Stöcker who wrote an obituary for Goldscheid in 1931 (Stöcker 1931, 206 f.). Goldscheid had also taken part in the international congress of the World League for Sexual Reform in Vienna 1930 and held a lecture there in which he demanded the drawing up of "sexual human rights" (Goldscheid 1931, $180)$. 
welfare for everyone. She realised Goldscheid's theory had to be understood as a branch of national economy but held that it must be elaborated further scientifically and should be made use of by the eugenic movement (Fürth 1929, 18 f.).

The German physician and sexologist Max Marcuse (1867-1963) used the term "Economy of Human Beings" in his "Handwörterbuch der Sexualwissenschaft" [Handbook of Sexology] (1923) as a synonym for "population policy", but not in the same sense as Goldscheid, in an article about "population science and population policy" (Marcuse 1923, 45). Max Marcuse had studied the use of contraceptives among the population in 1917 and also mentioned the connections between birth control and the declining birth rate. Like Goldscheid, he preferred the individual point of view instead of the national one on the dropping birth rate and warned against the mere production of quantity instead of quality. In his book "Der eheliche Präventivverkehr" [Marital Contraception] (1917) he did not name Goldscheid, but mentioned the Economy of Human Beings as a catchword. In short hints he stressed its humanitarian contents and its plea for sexual human rights (Marcuse 1917, 178).

In the "Handwörterbuch der Staatswissenschaften" [Handbook of Political Science] by Ludwig Elster, fourth edition, we do not find any mention of Goldscheid in the articles about "Population Science" or "Decline of the Birth Rate", but there is a reference in the article on "Eugenics" by Alexander Elster. Here Goldscheid is named together with the renowned German national economists Werner Sombart (1863-1941) and Franz Oppenheimer (1864-1943) as one of the very few scientists to have dealt with the question whether an "objective" evaluation of the abilities and performances of workers is possible, or if it is necessarily related to the attitudes and opinions of the surroundings. The "Economy of Human Beings" is quoted in a short sentence. Here Alexander Elster stresses Goldscheid's plea to manage the human capital economically, considering both hereditary dispositions and the surrounding milieu (A. Elster, 1926, 903). These examples may outline to some extent how Goldscheid's ideas were absorbed by the scientific community. Last but not least I want to hint that Goldscheid also propagated his ideas himself on the World Population Conference in Geneva 1927, when he took part in the discussion concerning the question of optimum population numbers. According to Goldscheid, the population optimum is reached when the desired population figure requires the least possible effort in reproduction (Sanger 1927, p. 104 f.).

\section{Short summary}

To sum up, we can state that Goldscheid's concept of the Economy of Human Beings was characterised by "alternative" features and provided other proposals for the solution of the problem of the decline in fertility than the ideas of contemporary professional population statisticians. Participants in the population discourse at the time did not pay sufficient attention especially to his proposal that the "human capital" be treated more carefully when there was a lack of labour force, which was thus to guar- 
antee national welfare despite a lower birth rate. The reason for this indifference was most likely Goldscheid's refusal to elaborate his studies according to the rules of the science of demography, i. e., to work out his ideas in detail, and also in the fact that he was not integrated in the scientific community-although he developed very modern ideas. Near the end of his life, Goldscheid seems to have been aware of this problem because he demanded the founding of a "research institute for the Economy of $\mathrm{Hu}$ man Beings" in a pro memoria which was printed in the "Finanzpolitische Korrespondenz" in 1928 (Fürth 1929, 18). According to Fleischhacker, it was also the general atmosphere in science and society which contributed to this ignorance, especially the widespread acceptance of social Darwinism and the rise of the eugenic movement (Fleischhacker 2002, 225), whereas Goldscheid always stressed the importance of the milieu. Goldscheid was ahead of his time in many regards. He also recognised war as a basic cause of population problems. Regarding the emancipation of women, he had a very modern point of view-in contrast to professional demographers at his time who preferred traditional views on woman's role in society.

A systematic compilation of his life and work-perhaps in the form of a Ph.D. thesis-still remains in need of research.

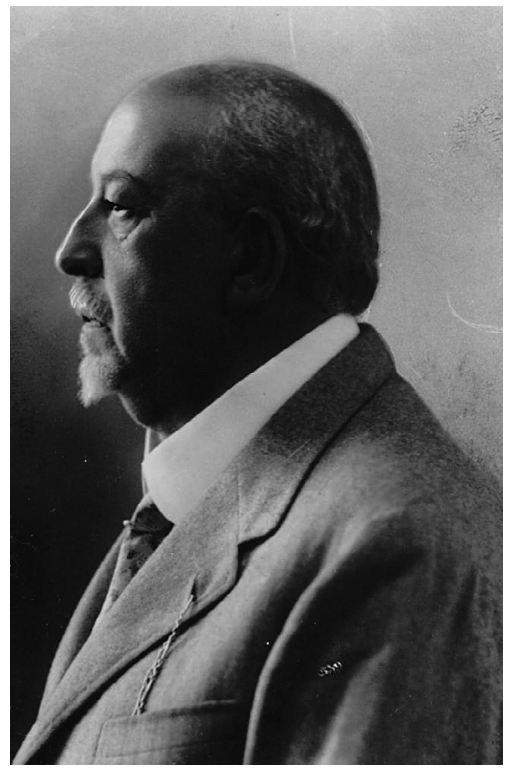

Picture 1: Picture of Rudolf Goldscheid. Undated. Retouched. Photograph: Austrian National Library / Department of Portraits.

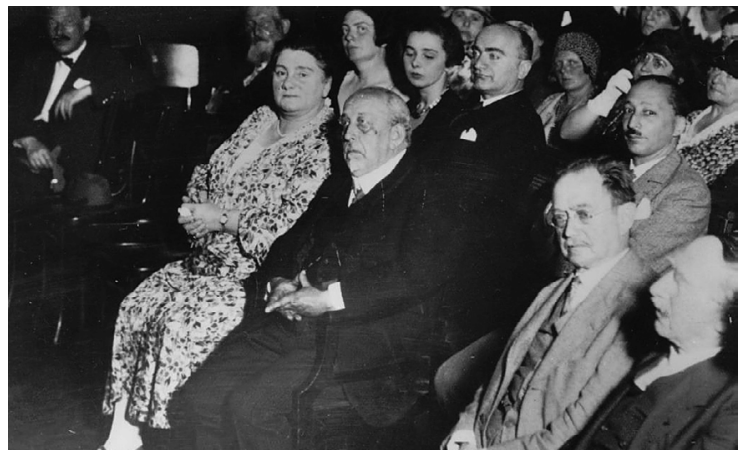

Picture 2: Group picture with Rudolf

G oldsc he id a d his wit party at his sixtieth birthday in 1930. Photograph: Austrian National Library / Department of Portraits.

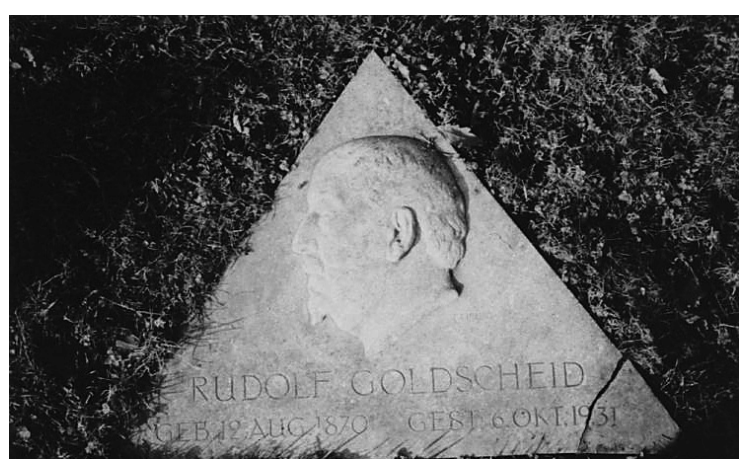

Picture 3: Gravestone at the Vienna Crematorium, Department VI, Ring II, Group 10, No. 123. Photograph: Gudrun Exner, 2003 


\section{References}

\section{Source materials}

Amtsblatt der Stadt Wien, Nr. 92, $18^{\text {th }}$ November 1931, p. 988.

Amtsblatt der Stadt Wien, Nr. 44, $1^{\text {st }}$ June 1932, p. 429.

Austrian National Library, Department of Portraits, photo Rudolf Goldscheid (undated), photo Rudolf Goldscheid ( $60^{\text {th }}$ birthday).

Goldscheid, R. 1908. Entwicklungswerttheorie, Entwicklungsökonomie, Menschenökonomie. Eine Programmschrift. Leipsic: Werner Klinkhardt.

Goldscheid, R. 1911. Höherentwicklung und Menschenökonomie. Grundlegung der Sozialbiologie. Leipsic: Klinkhardt.

Goldscheid, R. 1913. Ostwald als Persönlichkeit und Kulturfaktor. In: Wilhelm Ostwald, Festschrift aus Anlaß seines 60. Geburtstages. 2. September 1913. Hg. vom Monistenbund in Österreich. Vienna/Leipsic: Suschitzky, pp. 57-82.

Goldscheid, R. 1914a. Frauenfrage und Menschenökonomie. Vienna/Leipsic: Anzengruber.

Goldscheid, R. 1914b. Menschenökonomie als neuer Zweig der Wirtschaftswissenschaften. Allgemeines Statistisches Archiv 8, pp. 516-535.

Goldscheid, R. 1931. Zur Geschichte der Sexualmoral. Die Neue Generation. Publikationsorgan des deutschen Bundes für Mutterschutz 27, pp. 173-181.

Golm, R. [i. e. Rudolf Goldscheid]. 1888. Lord Byron. Ein Drama in einem Vorspiele und drei Aufzügen. Vienna: Breitenstein's Buchhandlung.

Golm R. 1894. Das Einmaleins des Lebens. Roman. Dresden/Leipsic: E. Pierson.

Golm, R. 1895. Der alte Adam und die neue Eva. Ein Roman unserer Übergangszeit. Dresden/Leipsic/Vienna: E. Pierson.

Golm, R. 1897. Ein falsches Liebeslied. Novelle. Dresden/Leipsic/Vienna: E. Pierson.

Municipal and provincial archives of Vienna, record of the coroner's inquest Nr. 35.603 (1938)

Municipal and provincial archives of Vienna, local court Margareten, property left Marie Goldscheid, $\uparrow 9^{\text {th }}$ November 1938.

Municipal and provincial archives of Vienna, local court Margareten, property left Rudolf Goldscheid, $\uparrow 6^{\text {th }}$ October 1931.

Municipal and provincial library of Vienna, Tagblattarchiv, Mappe "Rudolf Goldscheid".

Weiss, H., Jewish Community of Vienna, telephone call from $5^{\text {th }}$ March 2003, record.

\section{Literature}

Anderson, H. (ed.). 1988. Rosa Mayreder. Tagebücher 1873-1937. Frankfort on the Main: Insel Verlag. 
Arco, G. Graf, F. Hertz, R. Mayreder et al. 1930. Zu Rudolf Goldscheids 60. Geburtstag (12. August 1930)! Die Friedenswarte 30, pp. 193-202.

Bister, F. J. 2002. R. Goldscheid und die Österreichische Liga für Menschenrechte. In: M. G. Ash and C. H. Stifter (eds.), Wissenschaft, Politik und Öffentlichkeit. Von der Wiener Moderne bis zur Gegenwart. Vienna: WUV-Verlag, pp. 321-328.

Burgdörfer, F. 1932. Volk ohne Jugend. Geburtenschwund und Überalterung des deutschen Volkskörpers. Berlin-Grunewald: Kurt Vowinckel.

Byer, D. 2002. Evolutionistische Anthropologien. Zur Ambivalenz eines hundertjährigen Forschungsparadigmas. In: Mitchell G. Ash and Christian H. Stifter (eds.), Wissenschaft, Politik und Öffentlichkeit. Von der Wiener Moderne bis zur Gegenwart. Vienna: WUV-Verlag, pp. 185-206.

Elster, A. 1926. Eugenik und Eubiotik. In: Ludwig Elster, Adolf Weber and Friedrich Wieser (eds.), Handwörterbuch der Staatswissenschaften. $4^{\text {th }}$ edition, volume 3. Jena: Gustav Fischer, pp. 891-911.

Exner, G., J. Kytir and A. Pinwinkler. 2004. Bevölkerungswissenschaft in Österreich in der Zwischenkriegszeit (1918-1938). Personen, Institutionen, Diskurse. Vienna: Böhlau.

Fleck, C. 1990. Rund um "Marienthal”: von den Anfängen der Soziologie in Österreich bis zu ihrer Vertreibung. Vienna: Verlag für Gesellschaftskritik.

Fleischhacker, J. Undated manuscript. Fertility theories in the $20^{\text {th }}$ century. An examination of the theoretical demographic discourses of the sociologist Rudolf Goldscheid.

Fleischhacker, J. 1997. Change of generative models of behavior in the $20^{\text {th }}$ century. An examination of the theoretical demographic discourses of the sociologist Rudolf Goldscheid. Manuscript.

Fleischhacker, J. 2000. Rudolf Goldscheid, Soziologe und Geisteswissenschaftler im 20. Jahrhundert. Eine Porträtskizze. Newsletter. Archiv für Geschichte der Soziologie in Österreich 20, pp. 3-14.

Fleischhacker, J. 2002. Menschen- und Güterökonomie-Anmerkungen zu Rudolf Goldscheids demoökonomischem Gesellschaftsentwurf. In: Mitchell G. Ash and Christian H. Stifter (eds.), Wissenschaft, Politik und Öffentlichkeit. Von der Wiener Moderne bis zur Gegenwart. Vienna: WUV-Verlag, pp. 207-229.

Fürth, H. 1925. Das Bevölkerungsproblem in Deutschland. Jena: Gustav Fischer.

Fürth, H. 1929. Die Regelung der Nachkommenschaft als eugenisches Problem. Stuttgart: Julius Püttmann.

Grotjahn, A. 1914a. Geburtenrückgang und Geburtenregelung im Lichte der individuellen und der sozialen Hygiene. Berlin: Louis Marcus.

Grotjahn, A. 1914b. Der Geburtenrückgang im Lichte der sozialen Hygiene und Eugenik. Zeitschrift für Sexualwissenschaft 1, pp. 156-164.

Hecke, W. 1915. Der Geburtenrückgang und seine Statistik. Von Eugen Würzburger [Rezension]. Statistische Monatsschrift N. F. 20, pp. 585-587. 
Kautsky, K. jun. 1924. Der Kampf gegen den Geburtenrückgang. Kapitalistische oder sozialistische Geburtenpolitik. Vienna: Wiener Volksbuchhandlung.

Lehner, K. 1989. Verpönte Eingriffe. Sozialdemokratische Reformbestrebungen zu den Abtreibungsbestimmungen in der Zwischenkriegszeit. Vienna: Picus.

Marcuse, M. 1917. Der eheliche Präventivverkehr. Seine Verbreitung, Verursachung und Methodik. Dargestellt und beleuchtet an 300 Ehen. Stuttgart: Ferdinand Enke.

Marcuse, M. (ed.). 1923. Handwörterbuch der Sexualwissenschaft. Enzyklopädie der natur- und kulturwissenschaftlichen Sexualkunde des Menschen. Bonn: A. Marcus \& E. Webers Verlag.

Mitteilungen der Österreichischen Gesellschaft für Bevölkerungspolitik (und Fürsorgewesen). Heft 1-16 (1918-1937). Vienna.

Neue Deutsche Biographie, Bd. 6. 1971. Hg. von der Historischen Kommission bei der bayerischen Akademie der Wissenschaften. Berlin: Duncker \& Humblot, pp. $607 \mathrm{f}$.

Pinwinkler, A. 2003. Wilhelm Winkler (1884-1984) - eine Biographie. Ein Beitrag zur Geschichte der Statistik und Demographie in Österreich und Deutschland im 20. Jahrhundert. Berlin: Duncker \& Humblot.

Rudolf Goldscheid. Zu seinem 60. Geburtstag. 1930. Arbeiter-Zeitung Nr. 165, $15^{\text {th }}$ June 1930, p. 3.

Sanger M. (ed.). 1927. Proceedings of the World Population Conference. Held at the Salle Centrale, Geneva, August $29^{\text {th }}$ to September $3^{\text {rd }}$, 1927. London: Edward Arnold.

Stadler, F. 1981. Spätaufklärung und Sozialdemokratie in Wien 1918-1938. Soziologisches und Ideologisches zur Spätaufklärung in Österreich. In: Franz Kadrnoska (ed.), Aufbruch und Untergang. Österreichische Kultur zwischen 1918 und 1938. Mit einem Vorwort von Bundesminister Dr. Hertha Firnberg. Vienna/Munich/Zurich: Europaverlag, pp. 441-473.

St.[öcker], H. 1931. Rudolf Goldscheid, gest. 6. Oktober 1931. Die Neue Generation. Publikationsorgan des deutschen Bundes für Mutterschutz 27, pp. $206 \mathrm{f}$.

Tandler, J. 1916. Krieg und Bevölkerung. Wiener klinische Wochenschrift 29, pp. 445-452.

Tandler, J. 1917. Volksgesundheit und Volkswohlfahrt. Arbeiter-Zeitung Nr. 152, $5^{\text {th }}$ June 1917, p. 1 f.; Nr. 153, 6th June 1917, p. 1 f.

Uebel, T. 2000. Vernunftkritik und Wissenschaft: Otto Neurath und der erste Wiener Kreis. Vienna/New York: Springer.

Wehberg, H. 1931. Persönliches. Rudolf Goldscheid †. Die Friedens-Warte 31, p. 343.

Weikart, R. 2002. "Evolutionäre Aufklärung"? Zur Geschichte des Monistenbundes. In: Mitchell G. Ash and Christian H. Stifter (eds.), Wissenschaft, Politik und Öffentlichkeit. Von der Wiener Moderne bis zur Gegenwart. Vienna: WUV-Verlag, pp. 131-148. 
